\title{
Critical Thinking Ability Based on Science Process Skills With Numbered Head Together
}

\author{
Rahmanto Bayu ${ }^{1}$, Susilo $^{2}$, Rochmad $^{3}$ \\ \{galileo.may@gmail.com $\left.{ }^{1}\right\}$ \\ ${ }^{1}$ SDN Bandarharjo 02, Semarang, Indonesia, ${ }^{2,3}$ Graduate School, Universitas Negeri Semarang, \\ Indonesia
}

\begin{abstract}
The focus of the problem in this study is to improve students' critical thinking skills and analysis of critical thinking skills in terms of science process skills. The purpose of this study is 1 ) to describe the improvement of critical thinking skills;2) describe science process skills; 3) describe critical thinking skills in terms of science process skills. The design of this study uses quantitative. The sample of this study was the fifth grade students of Kangkung 1 Elementary School and Kangkung 3 Elementary School. The data collection was done by test, observation, interview and documentation methods. The results showed that critical thinking skills at the average of the pretest scores were 52 and posttest was 62 . Science process skills had a strong relationship with critical thinking skills. Students with high science process skills have critical thinking skills tend to be high or moderate, students with science process skills are having two tendencies of critical thinking skills which are moderate or low, but in this study there were no students with low science process skills. Hopefully this research will be a useful source of further research related to science process skills and critical thinking skills at the elementary school level.
\end{abstract}

Keywords: Critical thinking skills, Science process skills, $N H T$.

\section{Introduction}

In the global era, education must focus on developing strategies and solutions for solving common problems, meaning that teachers must consider the importance of using a learning approach built with various collaborative and participatory pedagogies. Basically the purpose of the 2013 curriculum is to create a learning process that provides a meaningful learning experience by developing various attitudes, knowledge and skills in students. Learning science should lead to the discovery and act so as to help students to acquire a more meaningful understanding of the natural surroundings (Agung, 2010).

The material of IPA was not enough is taught orally, because the characteristics of IPA consist of products and processes. Products in the form of factual knowledge, conceptual, procedural, and metacognitive while the IPA process in the form of scientific work. The ideal learning is learning that attention to both of these characteristics. Oral learning or by the lecture method only involves hearing the students, while meaningful learning requires the involvement of all the five senses of students in receiving the subject matter. Practicum is seen as an opportunity for students to be directly involved in learning (Defianti \& Hendri, 2015).

Effective science learning is learning to build a scientific attitude so that it builds the habit of applying scientific work to discover scientific concepts (products). Scientific work is the steps 
taken by scientists to conduct investigations in order to find an explanation of the symptoms of nature. Scientific work or known by the important science process skills be taught to students (USAID, 2014). The learning process which is oriented towards science process skills can train students to think scientifically and have good vocational skills since school (Wicaksana, 2017).

Science process skills are activities where students carry out scientific investigations that enable the acquisition of scientific knowledge and skills. The importance of teaching science process skills is to allow students to describe objects and events, ask questions, build explanations, test their explanations for scientific knowledge and communicate their ideas to others (Opara, 2011). One of the causes of low student learning outcomes is the weak learning process. The weak learning process in the class can be influenced by the low ability of students to think critically (Dasna, 2007).

The general symptoms that occur in students at this time are "lazy to think" they tend to answer a question by quoting from books or other library materials without expressing their opinions or analysis critically on that opinion. If this situation were to continue, the student will have difficulty applying the knowledge gained in the classroom to real life, so it is necessary for the development of science teaching that trains science process skills and higher level thinking to the peseta students to be able to solve the problem.

Science learning is very much related to high-level problem solving, it is necessary to train critical thinking skills for students. Teachers should not only focus on subject matter, but also think about how to develop students' critical thinking skills (Sukriadi, 2015). The critical thinking ability is important because it can improve the quality of thought for an individual to be skilled at analyzing, assessing, and reconstructing what he thinks to solve problems (Scriven, 2013).

\section{Methods}

The method in this research is quantitative with comparative research types. The design of data collection uses the type of pre-test post-test from the control group design. The subjects of this study were the fifth grade students of Kangkung 1 Primary School as an experimental class and the fifth grade students of Kangkung 3 Primary School as a control class in semester 2 of the 2018/2019 academic year. The research procedure is the pre-field phase, the field phase, and the post field phase. Data collection techniques used were tests and interviews for critical thinking skills, and observation for science process skills. The analysis uses normality test, homogeneous test, different test, and correlation test. data analysis using the spss software version 21.0

\section{Result and Discussion}

This study uses two sample classes as a control class and experimental class. Data collection began by giving a pretest to determine the initial conditions of both classes. After the pre-test, the next step was to conduct a normality test, and a homogeneous test to show that the two classes had the same variety, and the mean values of the two classes showed no significant difference. Experimental classes and control classes are given learning that focuses on science process skills, but there are different treatments. In the learning experiment class using the 
numbered head together model assisted with picture cards and in the learning control class using the lecture method.

Indicators of critical thinking skills used are indicators according to Ennis, namely; formulating questions, questioning and answering questions, conducting and assessing reports on the results of observations, making and considering results, defining and evaluating definitions and also combining (Costa, 2001).

Based on the results of the pre-test and post-test critical thinking skills in the experimental class, it can be seen that the average pre-test of critical thinking skills of the experimental class was 52 and the average post-test score was 62 . The results of experimental process science skills showed that the value of science process skills in practicum 1 is 63 and in practice 2 is 81 .

Recapitulation of the value of critical thinking skills and science process skills experimental class and control class can be seen in table 1 and 2

Table 1 Recapitulation of Values Critical thinking skills and science process skills in the experimental class

\begin{tabular}{lll}
\hline Value & Pre Test & Post Test \\
\hline Science Process Skills & 63 & 81 \\
\hline Critical Thinking Ability & 52 & 62 \\
\hline
\end{tabular}

Table 2 Value Recapitulation of critical thinking skills and science process skills in the control class

\begin{tabular}{lll}
\hline Value & Pre Test & Post Test \\
\hline Science Process Skills & 63 & 71 \\
\hline Critical Thinking Ability & 49 & 55 \\
\hline
\end{tabular}

After knowing the value of the pretest and posttest, the next step is a different test using the paired sample $t$ test in the experimental class. The paired sample $t$ test in this study was used to determine the differences in the average critical thinking skills and science process skills between the pretest and posttest experimental classes. The results of the paired sample $t$ test can be seen in Table 3 and Table 4

Table 3 Paired Sample T Test Results Critical Thinking Ability of the Experimental Class

\begin{tabular}{ccccc}
\hline & $\begin{array}{c}\text { Paired Differences } \\
\text { Mean }\end{array}$ & t & df & $\begin{array}{c}\text { Sig. } \\
\text { (2-tailed) }\end{array}$ \\
\hline Post Tes -Pre Test & 9.32000 & 3.954 & 24 & 0.001 \\
\hline
\end{tabular}

Based on the results of the calculation of the tcount is 3.954. The value of $\mathrm{df}=24$ and the significance level $=5 \%$ obtained the value of ttable $=1.711$. So it can be concluded that the value of $t_{\text {count }}>t_{\text {table }}$ then $\mathrm{H}_{0}$ is rejected. Then there are differences in the average between the value of pretest and posttest after applied learning with NHT models assisted by picture cards 
Table 4 Paired Sample T Test Results Science Process Skills in Experimental Classes

\begin{tabular}{ccccc}
\hline & $\begin{array}{c}\text { Paired Differences } \\
\text { Mean }\end{array}$ & t & df & $\begin{array}{c}\text { Sig. } \\
\text { (2-tailed) }\end{array}$ \\
\hline Practicum 2 - Practicum 1 & 6.24000 & 16.822 & 24 & 0.000 \\
\hline
\end{tabular}

Based on the results of the calculation of the tcount is 16.822 . The value of $\mathrm{df}=24$ and the significance level $=5 \%$ obtained the value of $t_{\text {table }}=1.711$. So it can be concluded that the value of $t_{\text {count }}>t_{\text {table }}$ then $\mathrm{H}_{0}$ is rejected. Then there are differences in the average between the value of science process skills in the treatment class students in practicum 1 and practicum 2.

Product moment or Pearson correlation test is used to state whether or not there is a relationship between science process skill (KPS) variables with critical thinking ability (KBK) variables. The value of rxy between critical thinking skills and science process skills of experimental class students can be seen in Table 5 .

Table 5 Product moment

\begin{tabular}{llll}
\hline & & KPS & KBK \\
\hline KPS & Pearson Correlation & 1 & $0.940^{* *}$ \\
& Sig. (2-tailed) & & 0.000 \\
& N & 25 & 25 \\
KBK & Pearson Correlation & $0.940^{* *}$ & 1 \\
& Sig. (2-tailed) & 0.000 & \\
& N & 25 & 25 \\
\hline
\end{tabular}

Based on Table 5, there is a correlation of 0.94 between the KPS variable and the KBK variable, this shows that the relationship between the two variables belongs to the strong correlation category.

Correlation only explains the strength of a relationship without regard to causality, which is influenced and which affects. Both variables can act as variables $\mathrm{X}$ and $\mathrm{Y}$ respectively, therefore a coefficient of determination is needed to find out how much the influence of the variable (KPS) affects the variable (KBK) of the treatment class students so the coefficient of determination technique is used.

Calculation of the coefficient of determination is done by squaring the product moment correlation coefficient (rxy2) and multiplied by $100 \%$. The moment product coefficient values of KPS and KBK students in the experimental class are 0.94 then $(\mathrm{rxy} 2) \times 100 \%=(0.94) 2 \mathrm{x}$ $100 \%=88.36 \%$. This means that $88.36 \%$ of KBK owned by students are able to be explained by the high and low KPS, while the remaining $11.64 \%$ may be caused by other factors

Based on the discussion of critical thinking skills in terms of science process skills, it can be concluded that students who have high science process skills will have high or moderate critical thinking skills. This can be seen in the achievement of indicators of critical thinking, the high critical thinking ability has an average high achievement, while the critical thinking ability is on average having moderate achievements. High process skills indicators that include indicators of observing, interpreting, asking questions, planning experiments, applying concepts, and communicating affect critical thinking skills because they are related to students' 
cognitive processes so as to produce accommodation. Advanced and superior thinking, advanced thinking is characterized by being able to analyze deeply while superior thinking can use high intuition (Elder \& Paul, 2010).

Based on the discussion of critical thinking skills in terms of moderate science process skills, it can be concluded that students with science process skills are likely to have moderate critical thinking skills and low critical thinking skills. This can be seen in the achievement of each indicator of critical thinking, each of which has a moderate achievement in students with moderate critical thinking skills. Students who have attainment of indicators of critical thinking skills are low, have critical thinking skills achievement, each indicator is moderate, but there are some low indicators. Indicators of achievement of critical thinking skills that are consistently prominent in students who have moderate science process skills are considering whether the source is reliable or not and observing and considering the report.

Students with moderate science process skills and critical thinking skills are unable to develop deep thinking processes, meaning that their thinking is still limited as evidenced by the questions that mention conclusions or the results of the analysis are not able to mention it in full. He has an imperfect memory and just realized when someone was reminded. The thinking process belongs to the category of initial thinking. Thinkers in the initial stage of thinking characterized by modifying some of their thinking abilities but having limited insight (Elder \& Paul, 2010).

\section{Conclusion}

Critical thinking ability of grade V students of elementary school on temperature and heat material has increased after learning with the number head together model assisted with picture cards

Science process skills have a strong relationship with critical thinking skills. Science process skills affect critical thinking skills by $88.36 \%$, while the remaining $11.64 \%$ may be caused by other factors.

Students with high process skills have a tendency for high critical thinking skills. Students with moderate process skills have two tendencies, namely having moderate or low critical thinking skills. 


\section{References}

[1] Agung W. 2010. Pentingnya Praktikum dalam Pembelajaran IPA. Prosiding, Kegiatan PPM "Pelatihan Pengembangan Praktikum IPA Berbasis Lingkungan" bagi guru-guru MGMP IPA SMP Kota Yogyakarta. Yogyakarta: MGMP Yogyakarta

[2] Costa, A. L. 2001. Developing Minds: A Resource Book for Teaching Thinking (3rded). Alexandria: VA. Association for Supervision and Curriculum Development.

[3] Dasna, I.W. \& Sutrisno. 2007. Makalah Pembelajaran Berbasis Masalah (Problem-Based Learning). Malang: Jurusan Kimia FMIPA Universitas Negeri Malang

[4] Defianti A., \& Hendri S., 2015, Pengembangan Alat Praktikum IPA Materi Gelombang dan Indra Pendengaran, Prosinding Simposium Nasional Inovasi dan Pembelajaran Sains, 8 dan 9 Juni 2015, Bandung

[5] Elder, L., \& Paul, R. 2010. Critical Thinking Development : A Stage Theory with Implications for Instruction. http://www.criticalthinking.org/pages/criticalthinking-development-a-stagetheory/483 (diunduh tanggal 22 Desember 2016).

[6] OECD. 2018. PISA 2015 Result in Focus. http://www.oecd.org/pisa/keyfindings (downloaded 20 Februari pukul 23.35 WIB)

[7] Opara, J. A. 2011. "Some Considerations in Achieving Effective Teaching and Learning in Science Education". Journal of Educational and Social Research. 1 (4): 85-90.

[8] Scriven, M. \& Paul, R. 2013. Defining Critical Thinking. http://www.criticalthinking.org/pages/defining-critical-thinking/410 (diunduh tanggal 4 Februari 2016)

[9] Sukriadi. Kartono \& Wiyanto. 2015. Analisis Hasil Penilaian Diagnostik Kemampuan Berpikir Kritis Matematis Siswa dalam Pembelajaran PMRI Berdasarkan Tingkat Kecerdasan Emosional. Unnes Journal of Mathematics Education Research. 4 (2) : 139 - 145.

[10] United States Agency for International Development USAID. 2014. Buku Sumber untuk Dosen LPTK Pembelajaran IPA SMP di LPTK. http:// www.prioritas pendidikan.org (downloaded 26 Desember 2015)

[11] Wicaksana, E. J., Maridi \& Sutarno. 2017. Efektivitas Modul Pembelajaran Biologi Berorientasi Integrated Scientific Process untuk Meningkatkan Vocational Skills Siswa SMA. Jurnal Pendidikan Biologi. 8 (2) : 64 - 69 